\title{
Variability of fresh- and salt-water marshes characteristics on the west coast of France: A spatio-temporal assessment
}

\author{
Sébastien Tortajada ${ }^{a, *}$, Valérie David ${ }^{a}$, Amel Brahmia ${ }^{a}$, Christine Dupuy ${ }^{a}$, \\ Thomas Laniesse ${ }^{a}$, Bernard Parinet ${ }^{b}$, Frederic Pouget ${ }^{a}$, Frederic Rousseau $^{a}$, \\ Benoit Simon-Bouhet ${ }^{a}$, François-Xavier Robin ${ }^{c}$ \\ a LIENSs, UMR 6250 Université de La Rochelle - CNRS, 2 rue Olympe de Gouge, 17000 La Rochelle, France \\ ${ }^{\mathrm{b}}$ LCME, UMR 6008 Université de Poitiers - CNRS, 15 rue de l'Hôtel Dieu, 86034 Poitiers Cedex, France \\ ${ }^{\mathrm{C}}$ Union des marais de Charente-Maritime, rue Jacques de Vaucanson Zone Industrielle de Périgny, 17180 Périgny, France
}

\section{A R T I C L E I N F O}

\section{Article history:}

Received 1 December 2010

Received in revised form

14 March 2011

Accepted 22 May 2011

Available online 31 May 2011

Keywords:

Marshes

Typology

Hydrodynamic

Eutrophication

Nitrate removing

Catchment basin

\begin{abstract}
A B S T R A C T
The degradation of water quality and the multiple conflicts of interest between users make marsh restoration very important. A Water Quality Evaluation System (WQES) was developed for river systems by the European Water Framework Directive (WFD). Some form of biologically-based, habitat-specific reference standard seems absolutely essential for wise management and stewardship of marsh ecosystems. The goal of this study was to develop a statistical method to define and to characterize a water body typology for drained marshes of the Charente-Maritime wetlands on the French Atlantic coast, placing particular emphasis on environmental factors as hydraulic functioning, human activities and pedological substratum. The Charente-Maritime marshes represent a good field study because of his high diversity of types of marshes and of anthropogenic activities in a restrictive area thus erasing spatial climatic effect (latitude effect). The statistical method developed here had permitted to define and characterize 12 different water bodies, 7 in freshwater (F1 to F7) and 5 in salt water marshes for the Charente-Maritime area. This typology demonstrated an important link between the size catchment area, nitrate concentrations, and leaching of precipitation from cultured soils. Even though the Charente-Maritime marshes are strongly impacted by humans, they may still retain the ability to remove nitrate. The increasing gradient of water renewal in the freshwater marshes from F1 to F7 explained the decreasing gradient of eutrophication. A better management of the hydrodynamic of the marshes can avoid eutrophication risk on the coastal sea area. Reliance on the WFD parameter set necessarily placed limits on the kinds of interpretations that could be made and on the study's potential contribution to the basic science of marshes. Ecologically-based insights regarding both external flows (links between ecosystems, meta-ecosystem theory) and internal flows (structure of the planktonic food web) seem an essential prerequisite for further advances in the study of marsh ecosystems.
\end{abstract}

(c) 2011 Elsevier Ltd. All rights reserved.

\footnotetext{
* Corresponding author. Tel.: +33 5465076 54; fax: +33 546507663 .

E-mail addresses: storta01@univ-lr.fr (S. Tortajada), valerie.david@univ-lr.fr (V. David), amel.brahmia@hotmail.fr (A. Brahmia), christine.dupuy@univ-lr.fr (C. Dupuy), thomas.lan@hotmail.fr (T. Laniesse), Bernard.Parinet@univ-poitiers.fr (B. Parinet), frederic. pouget@univ-lr.fr (F. Pouget), frederic.rousseau@univ-lr.fr (F. Rousseau), benoit.simon-bouhet@univ-lr.fr (B. Simon-Bouhet), fx.robin@ unima.fr (F.-X. Robin).

0043-1354/\$ - see front matter ( 2011 Elsevier Ltd. All rights reserved.

doi:10.1016/j.watres.2011.05.024
} 


\section{Introduction}

Increases in human population and levels of industrialization have produced growing demands for more water of better quality. Over time, requirements for water quantity and quality have emerged to provide water for drinking, personal hygiene, agriculture, industry, energy production and many additional purposes related to essential human needs (Meybeck and Helmer, 1996). Unfortunately, anthropogenic activities also impact water quantity and quality (Lotze et al., 2006) and therefore determine human access to potable water (Cominelli et al., 2009). In recognition of this basic human need, industrialized nations have in the past few years developed programs to restore the quality and the quantity of their natural freshwater and saltwater resources. The Ecological Society of America's research priorities for ecology have been in effect since 1988 (Lubchenco et al., 1991). Through its Water Framework Directive (WFD), the European Union has provided a holistic framework since 2000 for management and protection of all water bodies under its jurisdiction (Nõges et al., 2009).

Ecosystems provide goods and services to human populations. Wetlands serve very effectively to restore water quality (Millenium Ecosystem Assessment, 2005). Compared with other ecosystems, wetlands rank first for water supply and as habitat and refuge for organisms. They also rank first for waste treatment or nutrient cycling. They rank second for water regulation (Costanza, 1997). Sixty-seven percent of wetland surface area has been lost during the last 150 years. The result has been an inevitable degradation of water quality (Lotze et al., 2006), yet restoration of only $5 \%$ of a wetland area will purify $40 \%$ of nitrates introduced by agricultural activity (Verhoeven et al., 2006).

Marshes represent $50 \%$ of wetland area and provide $75 \%$ of the total services furnished by these systems (Costanza, 1997). Drainage of wetlands for human use through history has left few pristine freshwater or saltwater marshes. Today, the former marshlands are human-controlled ecosystems. Their hydrological functions depend now on human activities and decisions.

The degradation of water quality and the multiple conflicts of interest between users make marsh restoration very important. In Europe, the Water Quality Evaluation System (WQES) developed for river systems by the WFD is also applied to marshes because standard was not been developed for marshes. Majority of the study on freshwater marshes focused on macrofauna (birds and mammals) and on macrophytes diversity (Weller, 1978; Benoit and Askins, 1999; Lougheed et al., 2001). Freshwater marshes water quality is poorly studied all around the world and considered, in most cases, only one type of marshes (Rozas and Odum, 1988; Ahn and Mitsch, 2002; Mitsch et al., 1995; Rojo et al., 2010). Some form of biologically-based, habitat-specific reference standard seems absolutely essential for wise management and stewardship of marsh ecosystems and needs to be based on scientific knowledge of marshes functioning (Nõges et al., 2009). The first step in this understanding is to realize a water body typology presenting different functioning like the WFD recommended it (Nõges et al., 2009). A good field study with a high diversity of marshes types and a high diversity of anthropogenic activities in a restrictive area without latitudinal effect (latitude effect), is needed to develop standard.

The Charente-Maritime marshes (Atlantic Coast, France) are thus appropriate models to develop this standard since they present different types of environments (fresh, brackish or salt water) having a large range of hydrological controls (presence or absence of tidal effects, presence or absence of anthropogenic replenishment). The large range of human activities that they support include shellfish farming, agriculture, water purification facilities and cattle husbandry. Indeed, this area (including the 'Marennes-Oléron' Bay) is one of France's chief oyster-producing areas (Goulletquer and Heral, 1997). These contrasting human activities have produced several conflicts of interest over water quantity and quality (e.g., conflict between shellfish aquaculture and cereal farming). For example, oyster maturing are realized in ponds, downstream cereal production. The intensive irrigation and the use of pesticides provoked a deterioration of the water quality and quantity used to refill oyster ponds. This deterioration had strong impact on the oyster maturing (Gagnaire et al., 2007, 2006).

To realize a water body typology presenting different functioning on Charente-Maritime marshes, a strong statistical approach is proposed in this study in the perspective to be applicable at every kind of wetland zone. To better understand the functioning of each type of marshes, the statistical approach comprised a characterization step relating water body typology and environmental factors (i.e. anthropogenic activities, hydraulic functioning...). Our data source is a fiveyear survey database collected by stakeholders based on the standard set of physico-chemical and biological parameters proposed by the WQES. Our results will suggest meaningful assumptions about the biological functions of these marshes. Additional parameters will also be proposed whose clever use might well yield enhanced scientific understanding of the biological, bio-hydrological and eco-ethological functions of marshland ecosystems.

\section{Materials and methods}

\subsection{Study site}

The Charente-Maritime marshes of the French Atlantic coast $\left(46^{\circ} 10^{\prime}\right.$ North, $01^{\circ} 12^{\prime}$ West) are the second-largest French wetland zone (over $100000 \mathrm{ha}$ ). These marshes have been used for salt production since Roman times (Talureau, 1965). From the 12th to the 14th century these impoundments, progressively isolated from the sea, were invaded by freshwater and drained for salt production. From the 17th to the 19th century, further drainage allowed a major expansion of agriculture in the former marshlands (Talureau, 1965; Billaud, 1984). The coastal salt industry prospered until the 17th century. Since the 18th century the historic coastal salt culture has been replaced by oyster culture. Today the department of Charente-Maritime is the premier oyster producer in all of Europe (Lemonnier, 1980). This geographical area exhibits 
a high diversity of marsh types and anthropogenic uses. For example, one may find both tidal and non-tidal freshwater or brackish marshes. The area includes drained floodplain and drained marshes, both replenished and unreplenished. Tidal saltwater marshes are divided into multiple ponds. These ponds support a variety of human activities and facilities including oyster and fish farming, cattle husbandry, industrial plants, water purification facilities and saltern ponds. Each form of development produces different sorts of impacts on the water quality of the main channel. The drained marshes constitute a very significant artificial hydrographic network of channels and ditches (linear stretches of several thousand $\mathrm{km}$ ). Locks control this network so as to prevent drying and flooding throughout the year. Drying of replenished marshes is also limited by a replenishment channel that brings water from the Charente River during the summer.

From North to South, marshes occupy six geographical zones (Fig. 1): the Sèvre Niortaise River marshes (unreplenished, drained marshes), the Ré Island marshes (tidal marshes), the Rochefort marshes (replenished, drained marshes), the Seudre Estuary (tidal marshes), Oléron Island (tidal marshes) and the Gironde Estuary (non-tidal marshes).

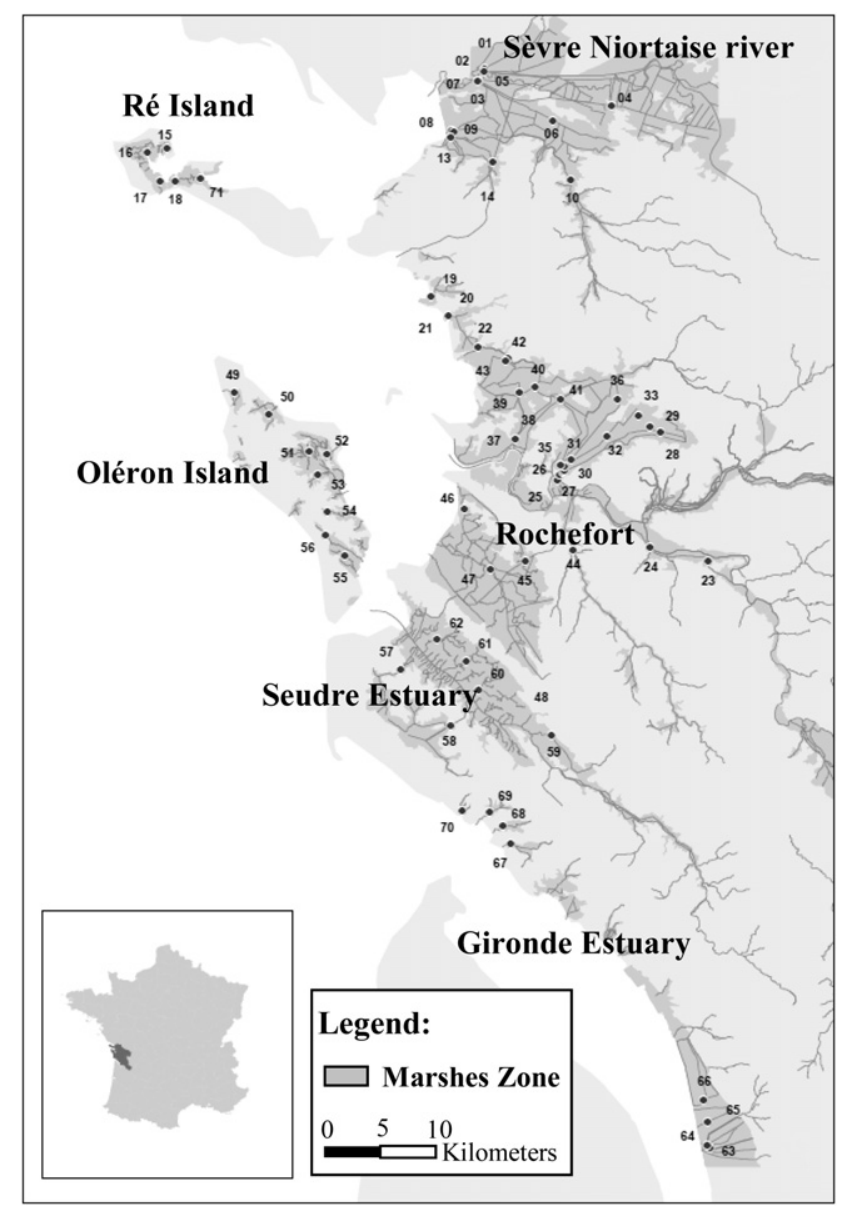

Fig. 1 - Map representing the 6 geographical zones of the marshes of Charente Maritime department and the stations at which stakeholders collected samples $(1,2$, 3...71).

\subsection{Sampling strategy}

A water quality monitoring program has been in place since spring 2003 on 51 stations located in all sections of the six geographical zones of marshes (Fig. 1). The stations were selected to represent (i) different types of marshes (tidal or non-tidal, drained or not drained, fresh, brackish or salt water); (ii) different soil uses (e.g., aquaculture, agriculture, or urban uses); (iii) different outlets (littoral, river, or channel); (iv) different anthropogenic impacts (e.g., farming or swimming); or (v) potential replenishment during summer. The methodology is based on protocols recommended by the WQES that were defined for the European WFD. From the overall collection of potential indicators proposed by the WQES, stakeholders selected several physicochemical and biological parameters to consider in the present study. Physicochemical parameters included temperature $\left(\mathrm{T}^{\circ} \mathrm{C}\right)$, conductivity/salinity (cond), dissolved oxygen concentrations, dissolved oxygen saturation $\left(\mathrm{O}_{2} \%\right)$, biological oxygen demand (BOD, standard NF EN 1899-2), concentrations of dissolved organic carbon (DOC standard NF EN 1484), suspended particulate matter (SPM, standard NF EN 872), nitrates $\left(\mathrm{NO}_{3}\right.$, standard NF EN ISO 13395), nitrites ( $\mathrm{NO}_{2}$, standard NF EN ISO 13395), phosphates $\left(\mathrm{PO}_{4}\right.$, standard ISO 15681-2), and ammonium $\left(\mathrm{NH}_{4}\right.$, (Aminot and Kérouel, 2004)). Biological parameters included chlorophyll a (Chl a) (Lorenzen 1967), pheopigment (Pheo) (Lorenzen 1967) and fecal bacteria (Escherichia coli and Enterococcus, standards NF EN ISO 9308-3 and 7899-1) concentrations. All parameters were measured six times per year ('winter' period -November, January, March- and 'summer' period - June, August, September)., except for the pigment concentrations ( $\mathrm{Chl}$ a and Pheo), which were sampled only during 'summer' periods (three samples a year).

\subsection{Statistical analyses}

Three databases were available. Two annual databases (6 months a year, 5 years, 51 stations) did not include pigment concentrations: one for fresh to brackish water marshes (AFM database) and one for salt marshes (ASM database). The summer database or $\mathrm{S}$ database ( 3 months a year, 5 years, 51 stations) included pigment concentrations. The statistical method was summarized in Fig. 2.

\subsubsection{Step 1: water body typology (Fig. 2)}

The regionalization method, adapted from (Souissi et al., 2000), was used to address spatio-temporal heterogeneity. This numerical analysis method for time series is based on successive Principal Component Analyses (PCA) and cluster analyses. A final cluster was obtained by using a similarity matrix that was used for subsequent PCA and cluster analyses. Correlations were prescreened before applying the time-series cluster method to eliminate redundancy among variables that would otherwise have ascribed excessive importance to multiple variables statistically associated with the same physical or biological quantity. For each node in the final cluster, an Approximately Unbiased (AU) p-value was calculated from successive random resampling (pvclust package for R software) (Suzuki and Shimodaira, 2006) to evaluate the uncertainty associated with the cluster. The 


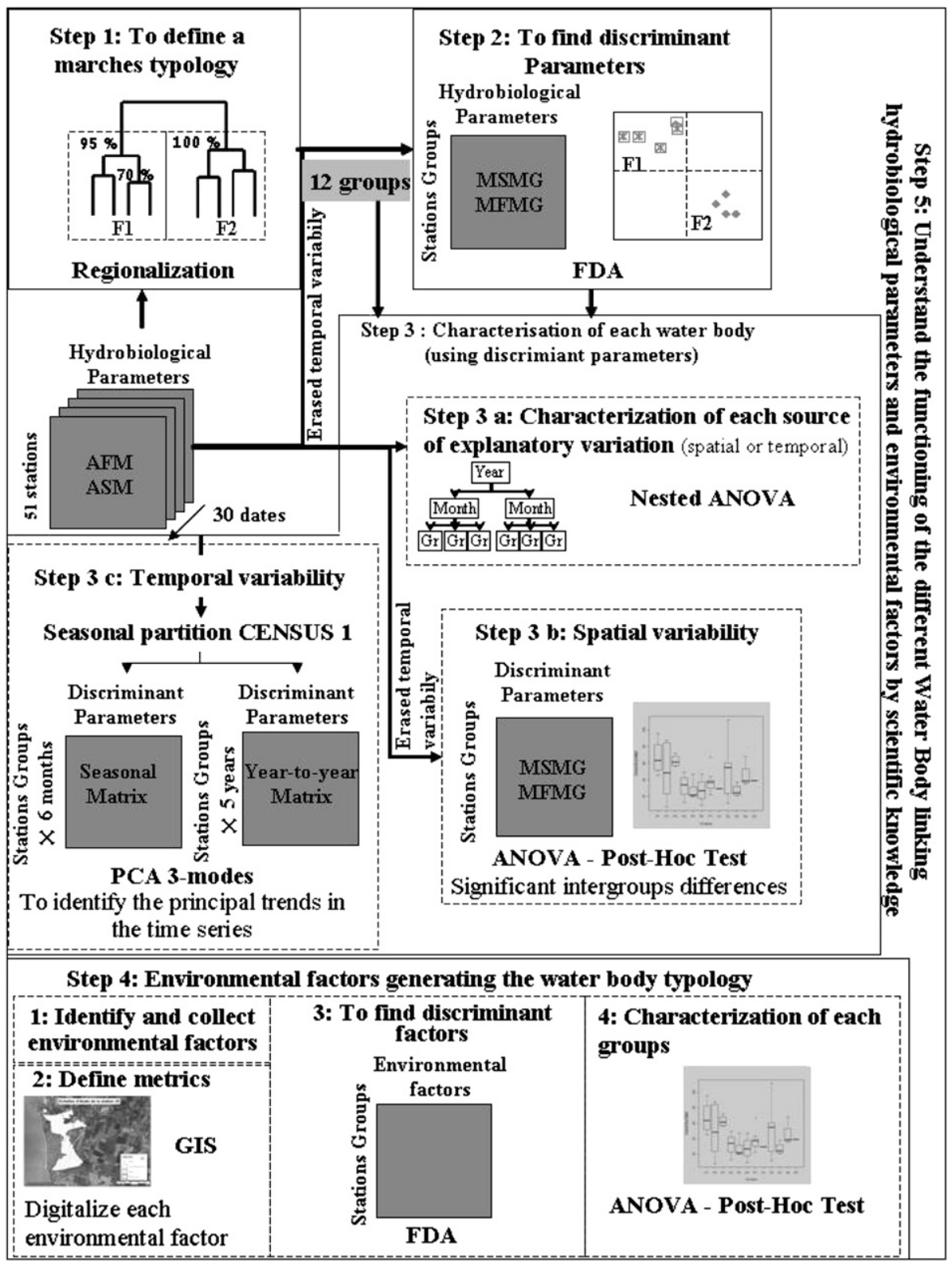

Fig. 2 - Diagram of the analysis steps that led to identify and characterize the water body typology.

regionalization method was applied on the AFM and the ASM databases.

\subsubsection{Step 2: discriminant parameters (Fig. 2)}

The regionalization method allowed us to discriminate among stations of the AFM and ASM databases that belonged to different water body groups without identifying the actual discriminating parameters (or variables). A Factorial Discriminant Analysis (FDA) was thus performed on the AFM and ASM databases modified to erased the temporal variability (mean annual values for each station) and to include groups found by the regionalization method (MFMG: mean freshwater marshes including groups; MSMG: mean saltwater marshes including groups); an FDA is a constrained Principal Component Analysis (PCA) in which groups are predefined.
2.3.3. Step 3: characterization of each water body (Fig. 2) The characterization of each water body was done with the discriminant parameters found thanks to the FDA.

2.3.3.1. Step 3a: characterization of each source of explanatory variation. To evaluate the relative importance of each source of spatio-temporal variability in explaining the fluctuations of physicochemical characteristics, a nested ANOVA design (Sokal and Rohlf, 1995) was applied to each parameter using the AFM and the ASM databases including groups. Three hierarchical levels (fixed factors) were considered. The nested model was structured according to groups (discriminated by the water body typology) within months within years. Interactions among factors were assumed negligible. This method allowed us to determine the overall significance of the factors 
as well as the relative importance of each factor in explaining fluctuations of the discriminant parameters (Dagnélie, 1975). Only these parameters were treated in the analysis.

2.3.3.2. Step $3 b$ : spatial variability. For each discriminating parameter and each group (MFMG, MSMG and MSG databases), a boxplot displaying the mean and the standard deviation was constructed to identify the chief differences between groups.

The boxplots provided a schematic overview of the variability of the different parameters for each group. Unfortunately, the method used to calculate the statistics displayed on the boxplots included an inherent bias. To compare different stations in the same group, we calculated a mean for each station using the entire database and therefore lost certain information (temporality). The strength of the regionalization method is that it accounts for temporal variability. A better understanding of the functional dynamics of each water body had thus been obtained from an additional study of temporal variability.

2.3.3.3. Step 3c: temporal variability. Year-to-year and seasonal variations of physicochemical parameters were derived for each group using the seasonal partition CENSUS 1 (additive model) (David et al., 2005).

A Three-Mode Principal Component Analysis (PCA) (Beaugrand et al., 2000, Goberville et al., 2010) was performed independently on each time series (year-to-year and seasonal series). This method is based on three different PCA applied to three different tables/modes: parameter mode (variables discriminating groups), spatial mode (water body typology, i.e., Fig. 2) and temporal mode (seasonal or year-to-year variability). This method allowed us to identify the principal trends in the time series and to compare them to the precipitation information to which the seasonal partition CENSUS 1 was applied (Météo France data). For each parameter and each group a two-way ANOVA was performed to analyze seasonal variation (months, first factor) and intra-group variability (stations, second factor).

\subsubsection{Step 4: environmental factors generating the water} body typology (Fig. 2)

An environmental factor is defined in this study as any natural or anthropogenic parameter having a potential impact on water quality. Such factors were relative to 1) hydraulic functioning, 2) human activities and 3) pedological substratum (Table 1). A factor can be measured using different metrics that represent the quantifiable values describing the factor state (Table 1). The first task in the analysis was to quantify all these metrics for each marsh using GIS (Geographic Information System) software $\left(\right.$ ArcGis $\left.^{\circledR}\right)$. Two databases were compiled, one for freshwater marshes and one for salt marshes. Data were available for

Table 1 - List of environmental factor taken into account. yes: Available data, no: no available data. Sources of data: (1) Union des Marais de Charente Maritime, (2) Syndicat des eaux de Charente Maritime, (3) Institut Géographique National, (4) Direction Départementale de l'Agriculture et des Forêts, (5) Institut Français de Recherche pour l'Exploitation de la Mer (6) Agence de l'Eau Loire-Bretagne and Agence de l'Eau Adour-Garonne (7) Bureau de recherches géologiques et minières.

\begin{tabular}{|c|c|c|c|}
\hline Factors & Metrics & Fresh marshes & Salt marshes \\
\hline \multicolumn{4}{|l|}{ Hydraulic functionning } \\
\hline \multirow[t]{6}{*}{ Web hydrographic structure } & Surface catchment basin (ha) $)^{(1)}$ & Yes & Yes \\
\hline & $\begin{array}{l}\text { Ratio between marsh surface and catchment } \\
\text { basin surface }(\mathrm{M} / \mathrm{BC})^{(1)}\end{array}$ & Yes & Yes \\
\hline & Channels density $\left(\mathrm{m} \mathrm{ha}^{-1}\right)^{(1)}$ & Yes & No \\
\hline & Distance to the see in meter ${ }^{(1)}$ & No & Yes \\
\hline & Position on the web: Primary channel or Secondary channel ${ }^{(1)}$ & No & Yes \\
\hline & Percentage of primary channels ${ }^{(1)}$ & Yes & No \\
\hline \multirow[t]{3}{*}{ Refeeding } & $\begin{array}{l}\text { Ground water replenished }{ }^{(2)} \text { (10: High replenishement, } \\
\text { 6.6: middle replenishement, 3.3: slow replenishement, } \\
\text { 0: no replenishement) }\end{array}$ & Yes & No \\
\hline & $\begin{array}{l}\text { Charente replenished }{ }^{(1)}(0 \text { : no replenishement, 5: replenishement, } \\
\text { 10: high replenishement) }\end{array}$ & Yes & No \\
\hline & $\mathrm{NO}_{3}$ concentration on ground water ${ }^{(2)}$ & Yes & No \\
\hline \multicolumn{4}{|l|}{ Human activities } \\
\hline \multirow[t]{7}{*}{ Land cover } & Percentage of construction ${ }^{(3)}$ & Yes & Yes \\
\hline & Percentage of wood ${ }^{(3)}$ & Yes & Yes \\
\hline & Percentage of cultur ${ }^{(4)}$ & Yes & Yes \\
\hline & Percentage of meadow ${ }^{(4)}$ & Yes & Yes \\
\hline & Percentage of saltern ponds ${ }^{(5)}$ & No & Yes \\
\hline & Percentage of shellfish culture ponds ${ }^{(5)}$ & No & Yes \\
\hline & Percentage of non exploited ponds ${ }^{(5)}$ & No & Yes \\
\hline $\begin{array}{l}\text { Water purification plant } \\
\text { Pedological substratum }\end{array}$ & Number of water purification plant by ha ${ }^{(6)}$ & Yes & Yes \\
\hline \multirow{4}{*}{ Pedological substrateum Nature } & Percentage of limestone ${ }^{(7)}$ & Yes & No \\
\hline & Percentage of peat ${ }^{(7)}$ & Yes & No \\
\hline & Percentage of alluvium ${ }^{(7)}$ & Yes & No \\
\hline & Percentage of silt ${ }^{(7)}$ & Yes & No \\
\hline
\end{tabular}


32 on 38 fresh marshes and for all salt marsh stations. An FDA was then performed for each database using 'Groups' as a constraint in order to determine which factors discriminated our group of stations. An ANOVA followed by a Post-Hoc test was then compiled on the different discriminant factor. The Post-Hoc test allowed classifying the different water body groups in homogenous classes: groups being in the same class did not present significant differences.

\section{Results}

\subsection{Water body typology}

We calculated (pairwise) correlations between all physicochemical parameters to eliminate redundant information, Significant correlations were found between salinity and conductivity ( $p<0.05, R=0.99$ ) as well as between dissolved oxygen concentration and dissolved oxygen saturation ( $p<0.05, R=0.92$ ) for the 'annual' database and between pheopigment and chlorophyll concentrations $(p<0.05$, $R=0.99$ ) for the 'summer' database. Salinity, dissolved oxygen concentration and pheopigment were thus eliminated from the database because of their close associations with conductivity, dissolved oxygen saturation and chlorophyll concentrations, respectively. Only the member of each correlated pair that would furnish more information about water conditions was retained.

The regionalization method was applied to the freshwater database. This analysis identified seven different groups of stations (Fig. $3 \mathrm{~A}$ ) associated in part with geographical zones: North Aunis marshes for F1 (stations 1-2-7-8), Gironde Estuary marshes for F3 (stations 47-63-64-65), North Aunis marshes for F4 (stations 3-4-5-6) and North Rochefort marshes for F7 (stations 22-23-24-34-37-38-40-41); these four groups are in contrast to three other groups, F2 (stations 9-13-19-20-44-6869), F5 (stations 10-21-45-4-59-70) and F6 (stations 36-48-6658), that contained stations located across the entire study area. Five different groups of stations were discriminated for saltwater marshes (Fig. 3 B). These groups were clearly associated with particular geographical zones: Ré Island for S1, S4 and S5 (stations 15, 16, 17, 18 and 71); Oléron Island for S3 (stations 51-52-53-55); and Oléron Island and Seudre Estuary for S2 (stations 60-61-62).

\subsection{Discriminant variables}

The method of regionalization classified the 51 stations of the database into 12 different water body groups. FDA identified the parameters responsible for discrimination by region.

The first and second axes of the FDA contributed $81 \%$ of the discriminant function for the freshwater database. The first axis was significantly explained by $E$. coli $(14 \%$ of the contribution), DOC (12.5\%), phosphate (10.5\%) and conductivity (6\%). The groups defined by the regionalization method (part 1) ranged from freshwater (low conductivity) with low E. coli, DOC and $\mathrm{PO}_{4}$ concentrations (groups F3, F6 and F7) to brackish water with high concentrations (group 1) (data not shown). The second axis was significantly explained by DOC (15\%), E. coli $(13 \%)$ and nitrate (11\%) concentrations discriminating groups with low concentrations (groups F2 and F4) from groups with high concentrations (group F5).

The saltwater body types were not discriminated by the same physicochemical parameters that discriminated the fresh and brackish types. The first two axes contributed to $98 \%$ of the discriminant function. The first axis explained $96 \%$ of the group discrimination with $35 \%$ of this contribution explained by conductivity, $17 \%$ by temperature, $15 \%$ by SPM, and $7 \%$ by dissolved oxygen saturation. The second axis explained only $2 \%$ of the group discrimination, with $42 \%$ of the contribution explained by BOD and $23 \%$ by DOC.

\subsection{Water body typology: characterization of each source of explanatory variation}

A nested ANOVA was conducted to identify the principal source of variation for the significant parameters of the FDA (Fig. 4). According to the nested ANOVA, the group effect was always significant $(p<0.05)$ for each parameter (except for Temperature) and explained most of the variation. The seasonal variability (month) was significant for temperature ( $87 \%$ of the total variance), SPM $(50 \%)$, dissolved oxygen saturation (49\%), $\mathrm{NO}_{3}(39 \%)$ and $\mathrm{BOD}(35 \%)$. Monthly variability was also significant for $\mathrm{PO} 4$ and salinity, but this variability contributed only slightly to the total variability for these parameters respectively $6 \%$ and $1.3 \%$ (Fig. 4). The year-to-year variance was significant for only four parameters: $\mathrm{BOD}, \mathrm{NO}_{3}$, dissolved oxygen saturation and temperature, but this variability explained no more than $16 \%$ of the total variance (for $\mathrm{NO}_{3}$ ).

A

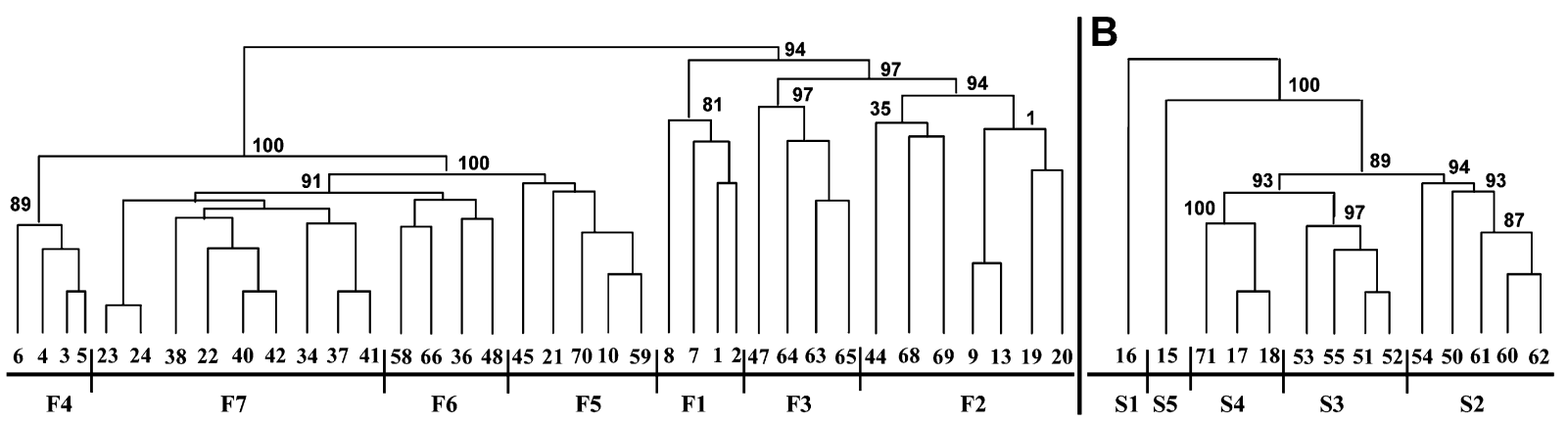

Fig. 3 - Final cluster resulting from the regionalization method applied to the annual database containing: A- fresh and brackish water and B- salt water. 89: AU p-value. 


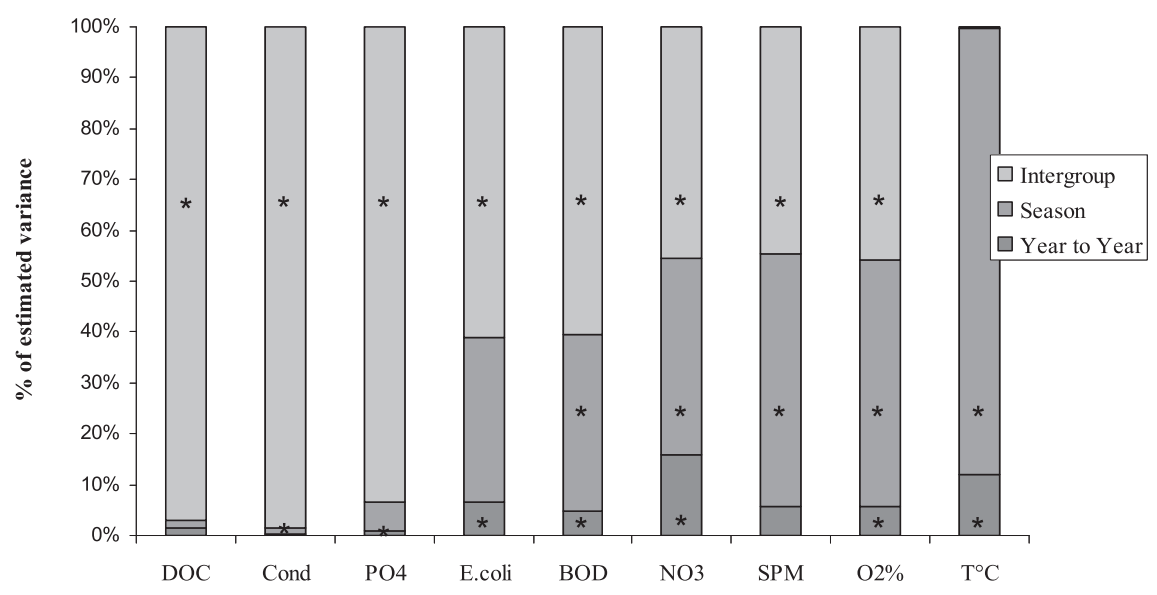

Fig. 4 - Percentage of estimated variance according to the nested ANOVA design (group within month within year) applied on the discriminant parameters. DOC: dissolved organic carbon, Cond: conductivity, $\mathrm{PO}_{4}$ : phosphate, E. coli: Escherichia coli concentration, BOD: biological oxygen demand, $\mathrm{NO}_{3}$ : nitrate, SPM: suspended matter, $\mathrm{O}_{2} \%$ : oxygen saturation, $\mathrm{T}^{\circ} \mathrm{C}$ : temperature. ${ }^{*}$ : significant differences $p<0.05$.

\subsection{Spatial variability}

Groups were classified according to decreasing summer chl a concentration (F1 to F7 for freshwater groups and S1 to S5 for saltwater groups, Fig. 4A). The gradient of chl $a$ was positively correlated with gradients of DOC and of BOD (Fig. $5 \mathrm{~A}, \mathrm{~B}, \mathrm{C}$ ). The chl a gradient was also positively correlated to $\mathrm{PO}_{4}$ but only for freshwater groups (F1 to F7, Fig. 5D). The highest values of $\mathrm{PO}_{4}$ were observed for the two Ré-Island groups (S1 and S5). Freshwater marshes (F1 to F7) were effectively discriminated by $\mathrm{NO}_{3}$ concentrations, with low $\mathrm{NO}_{3}$ for F1, F3 and F6, intermediate concentrations for F4 and high concentrations for F2, F5 and F7 (Fig. 5E). Saltwater marshes exhibited very low $\mathrm{NO}_{3}$ concentrations and high intragroup variability. F1 and F3 exhibited higher conductivity than the other freshwater marshes (Fig. 5F). S1 and S2 were less saline than the other saltwater marshes. Intragroup variability was very high for SPM and for oxygen saturation. However, these parameters were only effective discriminant for saltwater marshes (Fig. 5G,H). F1 and F2 have higher concentrations of $E$. coli than do other freshwater marshes (Fig. 5F).

\subsection{Temporal variability}

\subsubsection{Seasonal variability}

Significant seasonal variability was observed for temperature, DOC, $\mathrm{NO}_{3}$ and E.coli (Table 2). Some groups presented a higher amount of seasonal variability than others. In groups F1, F7 and S3 $67 \%$ of the variables exhibited seasonal variability. $55 \%$ of the variables exhibited seasonal variability for S2 and S4.

For the three-mode PCA applied to the seasonal series, the temporal mode (99.9\%) represented the greatest amount of variability, followed by the group mode (98.5\%) and the parameter mode (52\%, Fig. $6 \mathrm{~A})$. Three clusters were identified by a Hierarchical Ascendency Classification (HAC, Euclidean distance, Ward method). The first of these clusters regrouped freshwater marshes F6 and F7, the second regrouped freshwater marshes $\mathrm{F} 1$ to $\mathrm{F} 5$ and the last regrouped saltwater marshes S1 to S5 (Fig. 6A). The two latter clusters were not efficiently isolated by the two first axes of the PCA. Considering the three axes, our three groups are well clustered, but the 2-D representation did not allow seeing it. For the temporal mode, three seasons were separated using a HAC: winter (November to January), spring (March to June) and summer (August to September) (result of the HAC reported in Fig. 6B).

An interpolation of the first axis of the PCA in the parameter mode was constructed to determine the seasonal evolution of the different groups of marshes (Fig. 6B). The groups that were most correlated with axis 1 will exert the greatest influence on the formation of axis 1 . Higher curvature of the lines thus corresponds to greater differences between periods. The results indicated that the transition between the different periods was gradual and gentle. Variation was higher for the contrast of freshwater marshes than for salt marshes and exhibited a gradual shift from F1 to S5 (Fig. 6B). Groups F6 and F7 seemed to be transitional. Their properties looked like those of the other freshwater marshes during rainy months (November and January) and those of saltwater marshes during dry months (August and September).

\subsubsection{Year-to-year variability}

For the three-mode PCA applied to the year-to-year series, the temporal mode (99.9\%) exhibited the greatest variability, followed by the group mode $(98.1 \%)$ and the parameter mode $(60.8 \%)$. Three clusters were identified by the HAC. The first cluster regrouped freshwater marshes F6 and F7, the second cluster regrouped freshwater marshes F1 to F5 and the third cluster regrouped saltwater marshes S1 to S5 (Fig. 7A).

In an analysis similar to that used for seasonal variability (Fig. 7B), an interpolation of axis 1 of the PCA of the parameter mode was constructed to evaluate year-to-year variability. The results of this analysis were compared with those for the year-to-year evolution of precipitation (Fig. 7B). This comparison revealed a correlation of year-to-year evolution with precipitation. The transitions correspond to alternating dry and rainy periods with gentle, gradual transitions between the different periods. Variation was higher for freshwater 

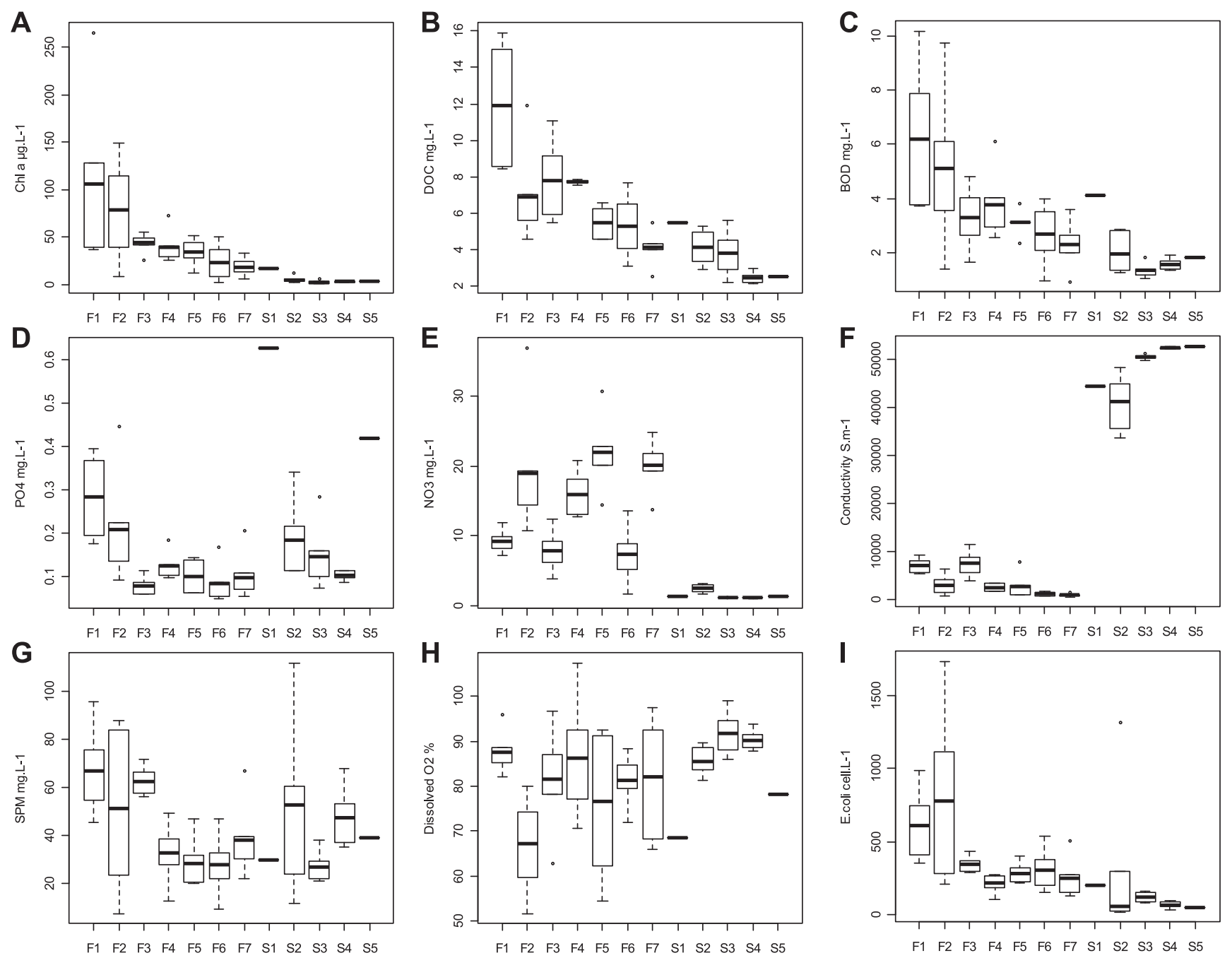

Fig. 5 - Boxplot displaying the mean per group for the following parameters (the temporal variability was erased): A- chlorophyll a (chl a) concentration, B- dissolved organic carbon (DOC) concentration, C- biological oxygen demand (BOD), D- phosphate $\left(\mathrm{PO}_{4}\right)$ concentration, E- nitrate $\left(\mathrm{NO}_{3}\right)$ concentration, F- conductivity, G- suspended matter (SPM) concentration, $\mathrm{H}$ - dissolved oxygen saturation and I- Escherichia coli concentration. F1 to S5: Groups of marshes found by the regionalization method.

marshes than for saltwater marshes (Fig. 7B). As previously found for seasonal variability, groups F6 and F7 seemed to be transitional between freshwater and saltwater marshes in accordance with the amount of precipitation.

\subsection{Relation between typology and environmental factors}

The groups identified by the regionalization method were used to constrain two discriminant factorial analyses (FDA) that included environmental factors (hydraulic functioning, human activities and pedological substratum): one for salt marshes and one for freshwater marshes.

- For the freshwater marshes, the first two axes of the FDA explained most of the variability (86\%) (Fig. 8A). Seven environmental factors significantly discriminated the freshwater groups. The extent of Charente replenishment, the $\mathrm{NO}_{3}$ concentrations in ground water, the number of WPP and the percentage of silt were strongly correlated with the first axis (49\%). The catchment basin index, the degree of replenishment by ground water, the channel density and the percentage of soil culture were correlated with the second axis (37\%). Most of these discriminant factors are involved with the hydrographical functioning of the network of marshes.

Significant differences between groups (ANOVA) were detected for all the environmental discriminant factors found by the FDA (Table 3) with the exception of the number of WPP and the percentage of silt. However, only two groups (F2 and F4) exhibited WPP in their marshes. The combined replenishment factors (replenishment by the Charente river and replenishment by ground water) seem to imply a water renewal gradient from F1 (no replenishment) to F7 (replenishment by the Charente). Perturbations of this gradient 
Table 2 - Results of the two-way ANOVA comparing seasonal variability ('month') and intragroup variability ('station') and their 'interactions', given as $p$-level ${ }^{* * *}: p<0.0001,{ }^{* *}: p<0.001,{ }^{*}: p<0.01$, ns: $\left.p>0.05\right)$. T ${ }^{\circ}$ : temperature, DOC: dissolved organic carbon, $\mathrm{NO}_{3}$ : nitrate, E. coli: Escherichia coli, Cond: conductivity, BOD: biological oxygen demand, SPM: suspended matter, $\mathrm{O}_{2} \%$ : oxygen saturation, $\mathrm{PO}_{4}$ : phosphate.

\begin{tabular}{|c|c|c|c|c|c|c|c|c|c|c|}
\hline Groups & ANOVA results & $\mathrm{T}^{\circ} \mathrm{C}$ & DOC & $\mathrm{NO}_{3}$ & E.coli & Cond & BOD & SPM & $\mathrm{O}_{2} \%$ & $\mathrm{PO}_{4}$ \\
\hline \multirow[t]{4}{*}{ F1 } & Factor 'Month' & $* * *$ & $* * *$ & $* * *$ & ns & $* *$ & $*$ & ns & $*$ & ns \\
\hline & Factor 'Station' & $* *$ & $* * *$ & * & ns & $* * *$ & ** & $* *$ & ns & ns \\
\hline & Interactions & ns & $* * *$ & ns & ns & ns & ns & ns & ns & ns \\
\hline & Factor 'Month' & $* * *$ & ns & $* * *$ & ns & ns & $*$ & ns & $* * *$ & ns \\
\hline \multirow[t]{3}{*}{ F2 } & Factor 'Station' & $* * *$ & $* *$ & ns & $* * *$ & ns & $* * *$ & $* * *$ & ns & ns \\
\hline & Interactions & ns & $*$ & $* *$ & ns & ns & ns & ns & $*$ & ns \\
\hline & Factor 'Month' & $* * *$ & $* * *$ & ns & ns & $* * *$ & ns & ns & ns & ns \\
\hline \multirow[t]{3}{*}{ F3 } & Factor 'Station' & ns & ns & ns & $*$ & $* *$ & ns & ns & ns & ns \\
\hline & Interactions & * & ns & ns & ns & ns & ns & ns & ns & ns \\
\hline & Factor 'Month' & $* * *$ & $* * *$ & $* * *$ & $*$ & ns & ns & ns & ns & ns \\
\hline \multirow[t]{3}{*}{ F4 } & Factor 'Station' & ns & $* * *$ & $* * *$ & $* * *$ & ns & ns & ns & ns & ns \\
\hline & Interactions & ns & ns & ns & ns & ns & ns & ns & ns & ns \\
\hline & Factor 'Month' & $* * *$ & $* * *$ & $* * *$ & $*$ & ns & ns & ns & ns & ns \\
\hline \multirow[t]{3}{*}{ F5 } & Factor 'Station' & ns & $* * *$ & $* * *$ & $* * *$ & ns & ns & ns & ns & ns \\
\hline & Interactions & ns & ns & ns & ns & ns & ns & ns & ns & ns \\
\hline & Factor 'Month' & $* * *$ & $* * *$ & $* * *$ & $*$ & ns & ns & ns & ns & ns \\
\hline \multirow[t]{3}{*}{ F6 } & Factor 'Station' & ns & $* * *$ & $* * *$ & $* * *$ & ns & ns & ns & ns & ns \\
\hline & Interactions & ns & ns & ns & ns & ns & ns & ns & ns & ns \\
\hline & Factor 'Month' & $* * *$ & $* * *$ & $* * *$ & $*$ & $* *$ & ns & $* * *$ & ns & ns \\
\hline \multirow[t]{3}{*}{ F7 } & Factor 'Station' & ns & $* * *$ & $* * *$ & $* * *$ & $* * *$ & ns & ns & ns & ns \\
\hline & Interactions & ns & ns & ns & ns & ns & ns & ns & ns & ns \\
\hline & Factor 'Month' & $* * *$ & $* * *$ & $* * *$ & $*$ & $* *$ & ns & ns & ns & ns \\
\hline \multirow[t]{3}{*}{ S2 } & Factor 'Station' & ns & $* * *$ & $* * *$ & $* * *$ & $* * *$ & ns & $*$ & ns & ns \\
\hline & Interactions & ns & ns & ns & ns & ns & ns & ns & ns & ns \\
\hline & Factor 'Month' & $* * *$ & $* * *$ & $* * *$ & $*$ & $* *$ & $* *$ & ns & ns & ns \\
\hline \multirow[t]{3}{*}{ S3 } & Factor 'Station' & ns & $* * *$ & $* * *$ & $* * *$ & $* * *$ & ns & $*$ & ns & ns \\
\hline & Interactions & ns & ns & ns & ns & ns & ns & ns & ns & ns \\
\hline & Factor 'Month' & $* * *$ & $* * *$ & $* * *$ & $*$ & $* *$ & $* *$ & ns & ns & ns \\
\hline \multirow[t]{2}{*}{ S4 } & Factor 'Station' & ns & $* * *$ & $* * *$ & $* * *$ & $* * *$ & ns & * & ns & ns \\
\hline & Interactions & ns & ns & ns & ns & ns & ns & ns & ns & ns \\
\hline
\end{tabular}

reflect the importance marsh surface area relative to catchment basin surface area $(\mathrm{M} / \mathrm{CB}$, the more the indices value is low, the more the catchment basin surface is important; F2, F4, F5 and F7; Table 3). In contrast, groups F1 and F3 were defined by a very small catchment basin (Table 3). The groundwater $\mathrm{NO}_{3}$ concentration was very high for group F4 (nearly $70 \mathrm{mg} \mathrm{l}^{-1}$ ) and very low for groups F1 and F7 (Table 3). Other groups exhibited intermediate values. Channel densities were high for F2, F3, F5 and F6 and low for F1, F4 and F7. Percentages of culture were high for F1, F3, F4 and F7 and low for F2, F5 and F6. Only the group F3 presents a low percentage of substratum silt (Table 3).

- For the saltwater marshes, the first two axes of the FDA captured essentially all of the variability $(100 \%)$ represented by the discriminating factors (Fig. 8B). Four environmental factors significantly discriminated the saltwater groups. Natural marshes, percentage of wood and shellfish culture were strongly correlated with the first axis whereas salt culture was correlated with the second axis. All the discriminant factors involved anthropogenic activities.

Significant differences between groups were found only for the following factors: number of unexploited ponds, saltern ponds and the area of the catchment basin (Table 4). Groups S1 and S5 were characterized by a very low percentage of shellfish culture ponds (1.5\% and 3.3\%, respectively). Most of the surface area of the S1 and S5 marshes was unexploited (75.8\% and $66.1 \%$, respectively; Table 4 ). The percentage of saltern ponds differed between these two groups: high value for S5 had a (11.9\%), and low value for S1 (1.5\%). The chief activity for the other groups was shellfish culture ponds (Table 4). S3 has a large catchment basin compared to the other groups (Table 4), whereas S4 is characterized by high salt culture activity (Table 4).

\section{Discussion}

\subsection{Statistical approach}

To understand the functioning of each type of marshes, a statistical approach was developed comprising a characterization step relating water body typology and environmental factors (i.e. anthropogenic activities, hydraulic functioning...) (Fig. 2). Such approach can now be applied to other areas. The first step of this approach was to define this typology using the five-year survey. The first challenge was to find a statistical approach clustering a high number of stations having the 

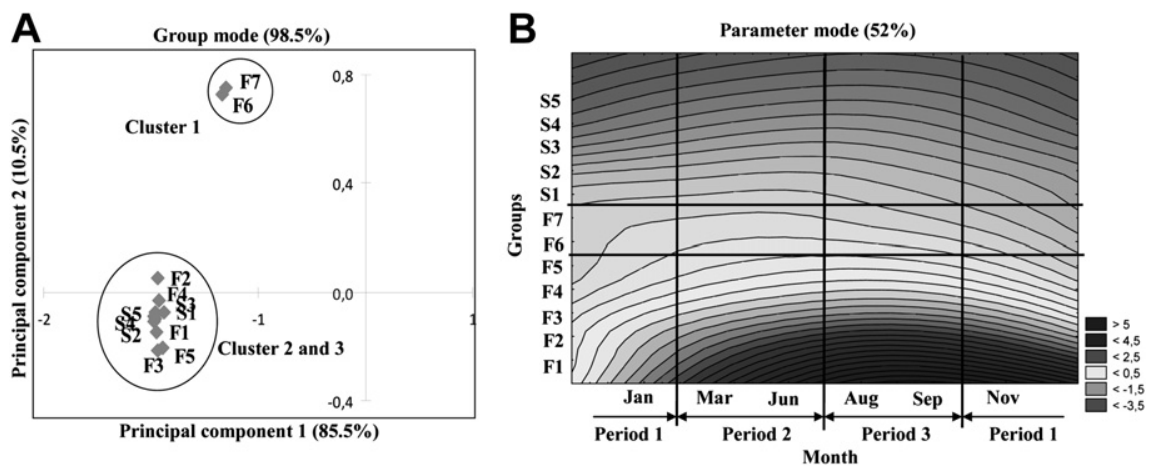

Fig. 6 - A- PCA representing the correlations between groups and the first and second principal components for the analysis of parameters and years. Percentage of variance explained by the components is given in parentheses. Groups were clustered into three zones, B- Variability of the first principal component for the analysis of months and groups derived using Parameters mode PCA. The gray shading indicates the intensity of the first component. The groups determined from the cluster analysis are indicated for month on the ordinate and for groups on the abscissa. Jan: January, Mar: March, Jun: June, Aug: August, Sep: September, Nov: November).

same patterns in terms of spatio-temporal variability. Souissi et al. (2000) had developed the 'regionalization method' in this way. Some amelioration of the method was done, in particular to test the significant of the groups found by the final cluster using the pv-clust method. This method is commonly used in phylogeny to cluster closed genetic species (Shimodaira, 2002). The 'regionalization method' is a powerful tool to cluster stations with a long-time series, however, it do not permit to find discriminant parameters. To have an idea of the functioning of the different water body, statistical tests were necessary to both study their spatial and temporal variability. To study the spatial variability, the temporal variability needed to be erased by computing a mean value on the five years for each station and each parameter. A Factorial Discriminant Analysis (FDA) was performed on this database. FDA allowed finding and classifying the parameters having the main effect on the typology. The Nested ANOVA had demonstrated the importance of seasonal and year-to-year variability. Each temporal variability was then extracted thanks to the seasonal partition CENSUS 1. To have a global vision of this temporal variability, 3-modes PCA were performed on these two new databases. The results of this method had permit to show same evolution across groups. Uses of FDA and 3-modes PCA had allowed describing this variability in a global view.

The second challenge was to analyze relationships linking this typology with such environmental factors as hydraulic functioning, human activities and pedological substratum. The majority of the similar studies focused on the effect of one environmental factor on the water quality: i.e. anthropogenic land used (Tong and Chen, 2002; Hussenot, 1998). The statistical method used here was developed in order to identify and classify the main environmental factors implied on the typology. The first step of this work was to realize the more
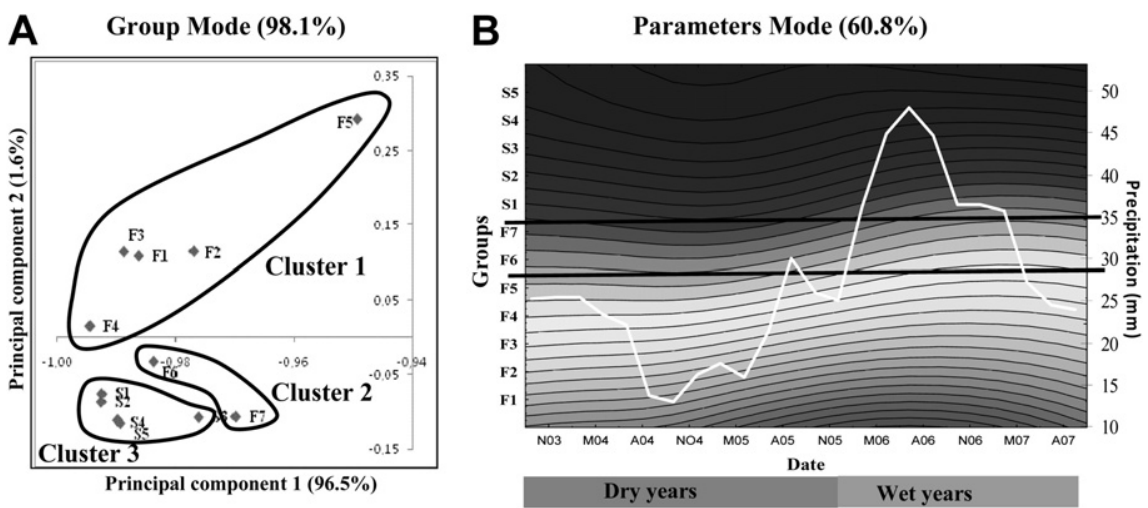

Fig. 7 - A- Group Mode: PCA representing the correlations between groups and the first and second principal components for the analysis of parameters and years. Percentage of variance explained by the components is given in parentheses. Groups were clustered into three zones, B- Parameters mode: Variability of the first principal component analysis of years and groups derived using Parameters mode PCA. The gray shading indicates the intensity of the first component. The groups determined from the cluster analysis are indicated for years on the ordinate and for groups on the abscissa. (M: March, A: August, N: November). The white curve represents the time course of precipitation between November 2003 and September 2007. 
A

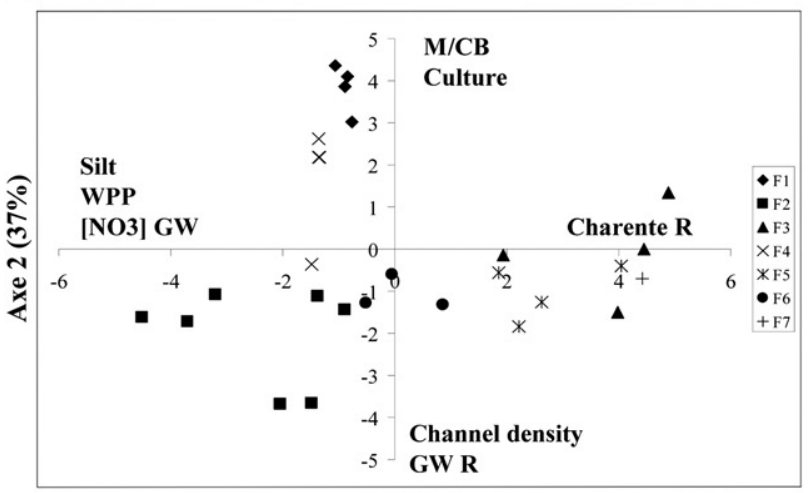

Axe $1(49 \%)$
B

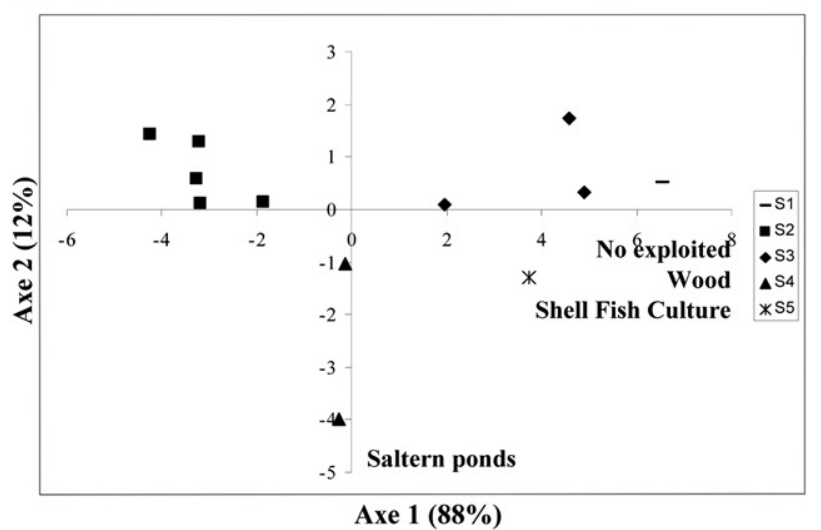

Fig. 8 - Factorial plane of DFA axis 1 and 2 for A- groups of freshwater marshes and B- groups of saltwater marshes. M/CB: ratio between surface marsh and surface catchment basin, $\mathrm{GW}$ : ground water, R: replenishement, [NO$\left.{ }_{3}\right]:$ nitrate concentration, WPP: water purification plant.

exhaustive list of environmental factor having potentially an impact on hydrobiological parameters and identify their availability. The complexity and the multiplicity of the environmental factors having a potential effect on the water quality had needed a global approach. The second step is to digitize these factors on a geographic information system (GIS) in order to define metrics (i.e. number of purification plant per ha, marshes and catchment basin surface area, channel densities inside the marsh...). This step allowed obtaining a database for each march with the different factors. An FDA was then computed in order to find and classify factors explaining the typology. The last challenge was to link these factors and the hydrobiological parameters thanks to scientific knowledge of other ecosystems.

These analyses yielded specific proposals regarding the biological functioning of these marshes. The results of our study also suggest that the use of further parameters might lead to an improved scientific understanding of marsh dynamics and function.

\subsection{Importance of hydrological functioning and water renewal}

Twelve groups of marshes were found to differ in both average values and temporal evolution of hydrological parameters (Fig. 2). Seven of these groups consisted of freshwater marshes and the five groups for saltwater marshes. Different discriminant parameters were found for the two types of marshes. Intergroup variability was consistently significant for all the discriminant hydrological parameters. Temporal variability, in particular seasonal fluctuations, was significant for most of the parameters as well (Fig. 3). Our considerations of seasonal variability and of year-to-year variability yielded the same three clusters of groups (Fig. 5A and Fig. 6A). The first cluster contained freshwater marshes (F1 to F5), and the second cluster contained saltwater marshes (S1 to S5). The third cluster contained freshwater marshes (F6 and F7) and was transitional between the two other groups. The functional hydrology of these three groups seems to be linked to precipitation with different behavior during dry periods and during rainy periods. Behavior of the transitional cluster during rainy periods is similar to that of freshwater marshes and during dry periods to that of saltwater marshes. The apparent difference in hydrological functioning among the three clusters seems to result from water renewal in the marshes. A gradient of water renewal was observed among the three clusters: (i) little or no renewal due to the low replenishment rates for the freshwater cluster (F1 to F5), (ii) high renewal for the transitional cluster (F6 and F7) and (iii) very high for the saltwater cluster due to the effect of the tide (S1 to S5). The amount of water renewal in freshwater marshes depends on the degree of replenishment from fluvial sources (the result of human control) and on the degree of replenishment from groundwater sources during summer (Table 3). Differences between rainy and dry periods were more marked for low-replenishment marshes (Fig. 5B and Fig. 6B). During winter, the gates of the sea locks for freshwater marshes are often opened to flush excess water resulting from precipitation and thereby limit the actual flooding of the marshes. These gates remain closed during summer to prevent desiccation that would otherwise results from low precipitation. Marshes were thus much more stagnant during summer than during winter, with the exception of freshwater marshes characterized by high human control replenishment rates (Group F7). Consequently, hydrological parameters exhibit their greatest temporal fluctuations in low-replenishment marshes (Fig. 5B and Fig. 6B). In this context the transitional position of group F6 and F7 is evidently the result of (i) a water renewal rate similar to that of other freshwater marshes during the rainy period, and (ii) a high water renewal rate during the dry period due to high human-control replenishment, a pattern similar to that found for saltwater groups. Tidal effects caused saltwater groups to exhibit high rates of water renewal in channel areas.

In saltwater marshes, the refill channel serves to return water during high tides to ponds located on the marshes. The types of activities (e.g., shellfish culture, saltern ponds, and fish aquaculture) carried out on these ponds seem to exert 
Table 3 - Mean ( \pm standard deviation) of the discriminant environmental factors for freshwater marshes. $p$-values (bold face) indicate significant differences among groups according to ANOVA $(\alpha=0.05)$, same letters $(A, B, C$ and $D)$ indicate homogenous classes (Cl) of groups according to LSD POST HOC test $(\alpha=0.05)$. M/CB: ratio between surface marsh and surface catchment basin, CD: channel density, GW: ground water, [NO $\left.{ }_{3}\right]$ : nitrate concentration, \%: percentage, Ch: Charente River. Metrics for each factor were explained in Table 1.

\begin{tabular}{|c|c|c|c|c|c|c|c|c|c|c|c|c|c|c|}
\hline \multirow[t]{2}{*}{ Groups } & \multicolumn{2}{|l|}{$\mathrm{M} / \mathrm{CB}(\%)$} & \multicolumn{2}{|c|}{$\mathrm{CD}\left(\mathrm{m} \mathrm{ha} \mathrm{a}^{-1}\right)$} & \multicolumn{2}{|c|}{$\mathrm{GW}\left[\mathrm{NO}_{3}\right]\left(\mathrm{mg} \cdot \mathrm{l}^{-1}\right)$} & \multicolumn{2}{|c|}{ Cuture (\%) } & \multicolumn{2}{|l|}{ Silt (\%) } & \multicolumn{2}{|c|}{ Ch replenishement } & \multicolumn{2}{|c|}{ GW replenishement } \\
\hline & Mean & $\mathrm{Cl}$ & Mean & $\mathrm{Cl}$ & Mean & $\mathrm{Cl}$ & Mean & $\mathrm{Cl}$ & Mean & $\mathrm{Cl}$ & Mean & $\mathrm{Cl}$ & Mean & $\mathrm{Cl}$ \\
\hline F1 & $97.1 \pm 5.5$ & A & $60 \pm 23$ & $\mathrm{~A}$ & $0 \pm 0$ & A & $68.1 \pm 7$ & A & $100 \pm 0$ & A & $0 \pm 0$ & A & $0 \pm 0$ & A \\
\hline F2 & $23.4 \pm 17$ & $\mathrm{D}$ & $114 \pm 21$ & B & $40 \pm 0$ & B & $35.6 \pm 20.6$ & B & $84.7 \pm 26.7$ & A & $0 \pm 0$ & A & $6.19 \pm 3$ & B \\
\hline F3 & $66 \pm 23.6$ & B & $125 \pm 40$ & B & $22.5 \pm 20.6$ & C & $45 \pm 33$ & A & $56 \pm 42$ & B & $0 \pm 0$ & A & $6.25 \pm 2.8$ & B \\
\hline F4 & $46 \pm 21$ & $\mathrm{C}$ & $75 \pm 9.5$ & $\mathrm{~A}$ & $70 \pm 0$ & $\mathrm{D}$ & $68 \pm 4.6$ & A & $98 \pm 2.3$ & A & $0 \pm 0$ & A & $6.33 \pm 0$ & B \\
\hline F5 & $32 \pm 10$ & B & $113 \pm 45$ & B & $32.5 \pm 15$ & B & $22.7 \pm 18$ & B & $70 \pm 27$ & A & $1.25 \pm 0.5$ & A & $8.33 \pm 1.9$ & $\mathrm{D}$ \\
\hline F6 & $31.12 \pm 16$ & B & $110 \pm 21$ & B & $26 \pm 23$ & B & $33 \pm 8$ & $\mathrm{~B}$ & $95 \pm 9$ & A & $3.33 \pm 0.6$ & B & $6.4 \pm 0.4$ & B \\
\hline F7 & 10.82 & $\mathrm{D}$ & 69.67 & A & 0.00 & A & 51.81 & A & 98.90 & $\mathrm{~A}$ & 10 & C & 0 & A \\
\hline $\begin{array}{l}\text { Anova } \\
\text { p-value }\end{array}$ & $<0.0001$ & & 0.030 & & $<0.0001$ & & 0.020 & & 0.156 & & $<0.0001$ & & 0.010 & \\
\hline
\end{tabular}

marked influence on the discrimination results for the salt marshes (Fig. 7B). Even if one activity dominates others within a salt marsh, the marsh still resembles a patchwork of several different activities (Table 4). However, the water residence time within the ponds varies between a few hours and 15 day depending on the nature of ongoing aquaculture activities (Bel Hassen, 2001) and also on the season of the year. For example, oyster culture ponds are never emptied into the refill channel during winter (L. Anras, pers. comm.). The composition of the water in a given refill channel will therefore vary from day to day depending on the particular ponds that empty into the channel at a given time. Differences in water residence times between ponds can influence water quality significantly. Hussenot (1998) showed that semi-intensive aquaculture (fish aquaculture) produced more pollution than did extensive aquaculture (shellfish culture). Semi-intensive aquaculture requires massive renewals of water. The massive discharges that result then carry untransformed dissolved substances, particularly nitrogen compounds $\left(\mathrm{NO}_{3}, \mathrm{NO}_{2}, \mathrm{NH}_{3}\right.$, etc.) and phosphate, introduced by aquaculture activity. In shellfish culture ponds, on the other hand, water residence times are comparatively longer. These ponds exhibit high primary production resulting from the assimilation of nitrogen compounds and phosphates. The physicochemical parameters can also be influenced strongly by the quality of coastal seawater. The S2 group was slightly less saline than the other salt marshes (Fig. 4F), and this decreased salinity is likely due to higher input of terrestrial freshwater in the S2 group
(Seudre Estuary marshes). Similarly, seawater can produce dilution effects that influence the various parameters. The sampling approach used in this study (samples collected at low tide at the outlet of the main refill channel) did not allow us to portray the full hydrodynamic complexity of the salt marshes, nor did it allow us to define a clear pattern linking the principal activity on the marshes and the physicochemical characteristics of the different saltwater bodies found there. It would be very interesting to monitor water quality simultaneously at the outlets of different ponds that supported different aquaculture activities as well as in the refill channel.

\subsection{Water renewal and eutrophication}

The increasing gradient of water renewal in the freshwater marshes from F1 to F7 described before could explain the decreasing gradient observed for hydrological and biological parameters, particularly for the chl a, BOD, DOC and $\mathrm{PO}_{4}$ concentrations (Fig. 4). The link between these four parameters may indicate a gradient of eutrophication from F1 (high eutrophication) to F7 (little or no eutrophication). Eutrophication is the process by which water bodies are made more nutrient-rich as the result of anthropogenic activities. Phytoplankton blooms are the usual consequence of such nutrient enrichment (Smith et al., 1999). In such eutrophic environments, the production of algae exceeds the consumption of grazers. The resulting accumulation of algal detritus

Table 4 - Mean ( \pm standard deviation) of the discriminant environmental factors for salt marshes (selected by the FDA). $p$ values in bold indicate significant differences among groups according to ANOVA $(\alpha=0.05)$, same letters indicate homogenous classes (Cl) of groups according to LSD post hoc test $(\alpha=0.05)$. CB: catchment basin, $\%$ : percentage.

\begin{tabular}{|c|c|c|c|c|c|c|c|c|c|c|}
\hline \multirow[t]{2}{*}{ Groups } & \multicolumn{2}{|c|}{ Wood (\%) } & \multicolumn{2}{|c|}{ Saltern ponds (\%) } & \multicolumn{2}{|c|}{ Shellfish Culture ponds (\%) } & \multicolumn{2}{|c|}{ No exploited ponds (\%) } & \multicolumn{2}{|c|}{ Surface CB (ha) } \\
\hline & Mean & $\mathrm{Cl}$ & Mean & $\mathrm{Cl}$ & Mean & $\mathrm{Cl}$ & Mean & $\mathrm{Cl}$ & Mean & $\mathrm{Cl}$ \\
\hline S1 & 1.9 & NS & 1.5 & A & 1.5 & NS & 75.8 & A & 826 & A \\
\hline S2 & $1 \pm 1.7$ & NS & $0.2 \pm 0.6$ & A & $23.9 \pm 30.2$ & NS & 16.6 & B & $1268.4 \pm 661.6$ & A \\
\hline S3 & $3.4 \pm 2.4$ & NS & $0.03 \pm 0.06$ & A & $32.2 \pm 12.8$ & NS & $54.3 \pm 11.3$ & $\mathrm{C}$ & $3801.8 \pm 1308.5$ & B \\
\hline S4 & $1.4 \pm 0.3$ & NS & $13.4 \pm 12.7$ & B & $22.2 \pm 14.8$ & NS & $50.2 \pm 19.8$ & C & $775 \pm 332.6$ & A \\
\hline S5 & 1.8 & NS & 11.9 & B & 3.3 & NS & $66.1 \pm 0.9$ & A & 1557 & A \\
\hline ANOVA p-value & 0.421 & & 0.066 & & 0.680 & & 0.006 & & 0.008 & \\
\hline
\end{tabular}


stimulates bacterial activity which then produces oxygen depletion in the water column (Strain and Yeats, 1999).

Phosphorus, rather than nitrates, demonstrably limits primary production in most freshwater ecosystems (Schindler, 1977). In stagnant waters, more phosphorus can be released to the water column from the sediment or from particulate organic phosphorus (POP). Sulfate accumulation resulting from agricultural activity and low water oxygen saturation facilitate this process by anion exchange (Correll, 1998; Lucassen et al., 2004). The measures of $\mathrm{PO}_{4}$ concentrations in this survey are not sufficient to explain the $\mathrm{PO}_{4}$ variation in water. It would seem necessary to consider both $\mathrm{PO}_{4}$ and POP concentrations. Nevertheless, the phosphorus gradient resulting from water stagnation can explain the chl a gradient (Fig. 4). Consistent with this supposition, the concentration of $\mathrm{NO}_{3}$ varied substantially along the water renewal gradient (Fig. 4). For example, groups F1 and F2 exhibited the highest values of $\mathrm{PO}_{4}$ and chl a concentration, whereas group $\mathrm{F} 1$ had less $\mathrm{NO}_{3}$ than did group F2 (Fig. 4E). Furthermore, a low N:P ratio may induce blooms of potentially-toxic nitrogen-fixing cyanobacteria. Under such environmental conditions, these cyanobacteria will outcompete other phytoplankton groups (Havens et al., 2003).

Rooted macrophytes and phytoplankton can also compete for nutrients. Many rooted macrophytes can extract nutrients from water as well as from sediment. Nutrient limitation is therefore less important for macrophytes than for phytoplankton, thus allowing them to outcompete phytoplankton (Sand-Jensen and Borum, 1991). Intense nutrient loading stimulates epiphyte growth on macrophyte leaves and stem and reduces macrophyte growth through shading and nutrient competition effects and favor phytoplankton growth. These processes will lead to eutrophication (Brönmark and Weisner, 1992). Analyses of the macrophyte community and phytoplankton diversity are essential to understanding the eutrophication mechanism in freshwater marshes, and such analyses could lead to better discrimination of the freshwater marshes. Nevertheless, along this gradient, a highly stagnant system such as F1 may be more sensitive to eutrophication than a system like F7. In such stagnant systems, algae lysates and extracellular products from algae can cause DOC to increase. DOC may then accumulate as its release rates exceed the DOC consuming by microorganisms (Cheng and Chi, 2003). The DOC gradient and chlorophyll a concentration gradient may therefore be linked. The simultaneous maxima that we observed for DOC and for chlorophyll a concentrations are consistent with this proposal. The same gradient was observed for biological oxygen demand (BOD). The BOD measures the consumption of oxygen by microorganisms through physiological respiration, particularly in relation to organic matter. The correlation observed between chlorophyll a concentration and BOD may suggest that detrital algal carbon is the primary contributor to BOD, as is the case in other ecosystems (Volkmar and Dahlgren, 2006). The availability of DOC produced by algae may also stimulate the growth of heterotrophic bacteria in eutrophic systems (Pinckney et al., 2001). A possible complication is that heterotrophic bacteria and phytoplankton may or may not compete for $\mathrm{NH}_{4}$, depending on the concentration of dissolved organic nitrogen (DON) (Legendre and Rassoulzadegan, 1995). If the DON pool is low, competition occur between production by phytoplankton and decomposition by bacteria (Legendre and Rassoulzadegan, 1995). Production will amplify eutrophication, but excessive decomposition will oppose it. When bacteria consume oxygen and DOC they increase the BOD in the water column. Their metabolic activity induces hypoxia, as we observed during summer for groups F1 and F2 (dissolved oxygen saturation reaching value between 6 and 25\% during summer period). This depletion of oxygen may in turn inhibit decomposition and remineralization of nutrients locked in biomass, thus inhibiting further phytoplankton production and halting growth. Measurements of DON concentration could therefore be extremely informative concerning the nitrogen cycle.

\subsection{Catchment basins and land (soil) use}

Freshwater marshes characterized by high $\mathrm{NO}_{3}$ concentrations exhibited large catchment basin areas relative to their marsh surface (groups F2, F4, F5 and F7; Fig. 4E, Table 3). The types of development (culture) that occupied these catchment basins tended to use nitrogen fertilizer, the main source of nitrates in water (Vitousek et al., 1997). A large catchment basin area relative to the marsh surface will be characterized by increases in $\mathrm{NO}_{3}$ concentration at the marsh sample point that are the consequences of leaching precipitation farmed soils (Wiesler and Horst, 1993). However, this pattern was not observed for groups F6 (marshes with large catchment basins but with low $\mathrm{NO}_{3}$ concentrations) and $\mathrm{F} 7$ (small catchment basins but high $\mathrm{NO}_{3}$ concentrations) (Fig. 4E, Table 3). The catchment basins of group F6 were occupied chiefly by meadow or were replenished by groundwater that contained essentially no nitrates. Group F7 is a cluster of stations associated with the Charente replenishment channel. The nitrate concentrations observed for F7 can be explained by the fact that the channel's nutrient concentration is close to nutrient concentration of the Charente River which drains a large catchment. Atmospheric precipitation following the use of nitrogen fertilizers may be a second source of nitrate. The amount of this input will depend on the surface area of the catchment basin (Morales-Baquero et al., 1999).

$\mathrm{NO}_{3}$ concentrations found for salt marshes were very low compared to those found for freshwater marshes (Fig. 4E). These concentrations reflect phytoplankton nutrient limitation. Such limitation results in most cases from limited nitrate availability in marine ecosystems (Arrigo, 2005). Nevertheless, $\mathrm{S} 2$ marshes exhibited the greatest $\mathrm{NO}_{3}$ concentrations among the salt marshes. The physical locations of these marshes seem to explain this result. Some of the S2 marshes are located along the Seudre Estuary, which may supply $\mathrm{NO}_{3}$ to these marshes. Other S2 marshes are located above Oléron Island. Their characteristics may therefore reflect strong influence by the input that feeds the catchment basin. This effect would not apply to the other salt marshes because they are located at the outlet of the main channel.

Nitrates showed strong seasonality for all fresh- and saltwater marshes except for those of S1. The seasonal nitrate maximum occurred during winter (maximum value $71.76 \mathrm{mg} \mathrm{l}^{-1}$ for fresh marshes and $9.03 \mathrm{mg} \mathrm{l}^{-1}$ for salt marshes). The lack of $\mathrm{NO}_{3}$ seasonal variation for $\mathrm{S} 1$ may be the result of regular nitrate input from a fish farm located near the 
sample point (Tovar et al., 2000). The seasonality of the other groups appears to be the result of high precipitation during winter. This precipitation leaches soil and brings $\mathrm{NO}_{3}$ from the catchment basin or from the farmlands on the marsh. During spring and to an even greater extent during summer, $\mathrm{NO}_{3}$ concentrations reached their lowest values $\left(>0.05 \mathrm{mg} \mathrm{l}^{-1}\right)$. These values were comparable to those observed in lakes (Andersen, 1982) or in marine ecosystems (Del Amo et al., 1997). This depletion of nitrates may result from phytoplankton assimilation during spring or summer blooms (Andersen, 1982), by denitrification (Seitzinger, 1988) or, in freshwater marshes, from uptake by riparian vegetation and by hydrophytes (Verhoeven et al., 2006). Indeed, the lack of plant growth during the winter due to limited sunlight may lead to the accumulation of nitrate during this season.

In salt marshes, uptake of nitrate by phytoplankton and microphytobenthos may result in $\mathrm{NO}_{3}$ depletion. At the autotrophic base of the food web, we may find competition between phytoplankton, microphytobenthos and hydrophytes for light, nutrient and inorganic carbon (Sand-Jensen and Borum, 1991). Microphytobenthos can actually develop on their banks and resuspension can occur due to tidal activity and specific meteorological events which caused a benthicpelagic coupling (Guarini et al., 2008).

Further study of this ecosystem component may lead to improved scientific understanding of $\mathrm{NO}_{3}$ depletion mechanisms. In addition, Verhoeven et al. (2006) argued that wetlands contribute significantly to $\mathrm{NO}_{3}$ removal if they remove at least $30 \%$ of the $\mathrm{NO}_{3}$ load. For each group, we observed levels of $\mathrm{NO}_{3}$ removal that always exceeded $30 \%$. We found $>80 \%$ for F1, F4, F6, S1 and S2, between $70 \%$ and $80 \%$ for F2, F7 and S4 and between $60 \%$ and 70\% for F3, F5 and S3 (ratio between the highest value of $\mathrm{NO}_{3}$ in winter and the lowest in summer). This conclusion may imply that even though the Charente-Maritime marshes are strongly impacted by humans, they still retain the ability to remove nitrate, an important characteristic of wetlands. This suggestion needs to be viewed with some caution because eutrophication may occur in groups F1 and F2 and because of the bias inherent to the calculation. The calculation method (ratio between winter and summer value) imply winter water stagnation but like it is described before, during high precipitation event, water marshes are evacuate to the sea. Eutrophication also removes $\mathrm{NO}_{3}$, but the consequences of such eutrophication are harmful for the ecosystem and may include shifts in phytoplankton species composition to taxa that may be toxic or inedible (e.g., bloom-forming cyanobacteria), and dissolved oxygen depletion in the water column that induces shifts in fish species composition towards less desirable species and, in the worst case, increased fish kills (Smith et al., 1999). Bloom-forming cyanobacteria were recently observed in several CharenteMaritime marshes in late summer during eutrophication phenomena (no published data).

\subsection{Which additional parameters could improve water quality monitoring?}

Twelve different water body types were defined and classified. This typology made sense in terms of anthropogenic hydraulic controls and in terms of soil use. The resulting interpretations were complex. The chief source of this complexity was that overall ecological understanding was restricted by the parameters available for analysis. The parameters that were available to us from stakeholder surveys were those used by the WFD to evaluate water quality in rivers. Reliance on the WFD parameter set necessarily placed limits on the kinds of interpretations that could be made and on the study's potential contribution to the basic science of marshes. Rivers and marshes differ in significant ways. For example, different hydrodynamic regimes could occur because water is more stagnant in marshes than in rivers. The particular parameters used for rivers by WQES might well be incomplete for describing and for understanding marsh function. The need remains for appropriate scientific studies that will facilitate interpretation of measured WFD parameters and lead to better scientific understanding of the ecological patterns and functional mechanisms underlying our marsh typology. Available measurements of the WFD parameters are generally expressed as concentrations. However, to better understand the complexity of marsh ecosystems, we need to go beyond isolated point measurements and to consider external flows (energy or matter exchanges between ecosystems) and internal flows (energy or matter exchanges within the ecosystem). In fact, the Charente-Maritime salt and freshwater marshes are connected hydraulically to adjacent ecosystems. The connections of the catchment basin or of the river/groundwater will influence water quality and quantity in the marshes. Marsh water quality and quantity will influence coastal seawater when sea lock gates are opened during periods of high precipitation and water drains from the marshes to the sea. The connection between saltwater marshes and the coastal zone is a two-way street, an important link in a complex, dynamic and still poorly understood network that includes ecological causation, interactions and relationships -complexity mainly due to the difference of water residence time within the ponds according to the activity. Interactions between differently-functioning ecosystems produce a 'meta-ecosystem': an ecosystem connected by spatio-temporal flows of energy, materials and organisms across ecosystem boundaries (Loreau et al., 2003). Improved understanding of the origin of the organic matter involved in all these flows (allochthonous/autochthonous, phytoplankton/ microphytobenthos/bacteria and marine/terrestrial) should allow better definition of such exchanges and the interactions they produce. The origin of the organic matter could be identified by using different methods as isotopic ratio of the POM (Galois et al., 2000) and/or 3-D fluorescence of the DOM. Furthermore, the results of this study highlight the overall importance of the biota and the role of the planktonic community in eutrophication and in $\mathrm{NO}_{3}$ removal. Of equal overall importance is recognition that benthic-pelagic coupling in salt marshes can result from resuspension of microphytobenthos. To achieve better scientific understanding of the functioning of the different water bodies, it seems crucial to study the linkages and the temporal evolution of the different planktonic compartments (from bacteria to mesozooplankton). Such studies necessarily require detailed examination of the planktonic food web (i.e. grazing activity, bacterial and phytoplanktonic production) and of the patterns that characterize its changing dynamics in space and 
time. Appropriate consideration of the unique functional properties of the planktonic food web, as defined by Legendre and Rassoulzadegan (1995) and Sintes et al. (2004), could shed new light on the following functional characteristics of marshes: 'purification' by the recycling of material components, exportation of matter to adjacent ecosystems or ecotrophic efficiency.

\section{Conclusions}

- A statistical method was developed to define and characterize a marsh water body typology. For the CharenteMaritime area, twelve different water bodies were defined: 7 in freshwater and 5 in saltwater marshes). This statistical method should be applied in other marshes area to improve the sensibility of this typology.

- This typology made sense in terms of natural and anthropogenic hydraulic controls and in terms of soil use. However, for saltwater marshes, the sampling approach used in this study did not allow us to define a clear pattern linking the principal activity and the physicochemical characteristics of the different saltwater bodies found there because of the complexity of the hydrodynamic features in those marshes.

- The size of the catchment basin and particularly the soil use (culture) influence strongly nitrates concentration inside the freshwater marshes. Even though the CharenteMaritime marshes are strongly impacted by humans, they may still retain the ability to remove nitrate, an important characteristic of wetlands.

- The increasing gradient of water renewal in the freshwater marshes from F1 to F7 explained the decreasing gradient of eutrophication. Freshwater marshes are at the interface between the continent and the sea: catchment basin water quality will influence marshes and water quality marshes will influence water coastal area. A better management of the hydrodynamic of the marshes mainly human control can avoid eutrophication risk on the coastal sea area which sustains a great oyster culture production.

- The European Water Framework Directive (WFD) furnished a common frame of reference that supported the analysis of marshes and is likely suitable for comparisons of other complex aquatic ecosystems. However, we feel that improved scientific understanding of the resulting typologies can also stem from a broader ecological approach. In particular, ecologically-based insights regarding both external flows (links between ecosystems, meta-ecosystem theory) and internal flows (structure of the planktonic food web) seem an essential prerequisite for further advances in the study of marsh ecosystems.

\section{Acknowledgments}

This study was supported by the " Ministère de l'Enseignement Supérieur et de la Recherche », the water agencies Loire-
Bretagne and Adour-Garonne, conseil général de CharenteMaitime, European Union. Thanks are extended to Christian Pointillard and Serena Como for their helpful suggestions.

\section{REFERENCES}

Ahn, C., Mitsch, W.J., 2002. Scaling considerations of mesocosm wetlands in simulating large created freshwater marshes. Ecological Engineering 18 (3), 327-342.

Aminot, A., Kérouel, R., 2004. In: Hydrologie des écosystèmes marins: paramètres et analyses. IFREMER Publishing, Plouzané, France.

Arrigo, K.R., 2005. Marine micoorganisms and global nutrient cycles. Nature 437 (7057), 349-355.

Andersen, J.M., 1982. Effect of nitrate concentration in lake water on phosphate release from the sediment. Water Research 16 (7), 1119-1126.

Beaugrand, G., Ibanez, F., Reid, P.C., 2000. Spatial, seasonal and long-term fluctuations of plankton in relation to hydroclimatic features in the English Channel, Celtic Sea and Bay of Biscay. Marine Ecology Progress Series 200, 93-102.

Bel Hassen, M., 2001. Spatial and temporal variability in nutrients and suspended material processing in the Fier d'Ars Bay (France). Estuarine. Coastal and Shelf Science 52 (4), 457-469.

Benoit, L., Askins, R., 1999. Impact Impact of the spread of Phragmites on the distribution of birds in Connecticut tidal marshes. Wetlands 19 (1), 194-208.

Billaud, J.-P., 1984. Marais Poitevin: rencontres de la terre et de l'eau. In: Mendras, H., Jollivet, M. (Eds.), Ecrits et travaux du groupe de sociologie rurale du CNRS. L'Harmattan Publishing, Paris, France, p. 265.

Brönmark, C., Weisner, S.E.B., 1992. Indirect effects of fish community structure on submerged vegetation in shallow, eutrophic lakes: an alternative mechanism. Hydrobiologia 243-244 (1), 293-301.

Cheng, W.P., Chi, F.-H., 2003. Influence of eutrophication on the coagulation efficiency in reservoir water. Chemosphere 53 (7), 773-778.

Cominelli, E., Galbiati, M., Tonelli, C., Bowler, C., 2009. Water: the invisible problem. EMBO Reports 10 (7), 671-676.

Correll, D.L., 1998. The role of phosphorus in the eutrophication of receiving waters: a review. Journal of Environmental Quality 27 (2), 261-266.

Costanza, R., d'Arge, R., de Groot, R., Farber, S., Grasso, M., Hannon, B., Limburg, K., Naeem, S., O’Neill, R.V., Paruelo, J., Raskin, R.G., Sutton, P., van den Belt, M., 1997. The value of the world's ecosystem services and natural capital. Nature 387 (6630), 253-260.

Dagnélie, P. (Ed.), 1975. Théorie et méthodes statistiques: Applications Agronomiques. Les presses agronomique de Gembloux Publishing, Gembloux, Belgica, p. 464.

David, V., Sautour, B., Chardy, P., Leconte, M., 2005. Long-term changes of the zooplankton variability in a turbid environment: the Gironde estuary (France). Estuarine, Coastal and Shelf Science 64 (2-3), 171-184.

Del Amo, Y., Le Pape, O., Treguer, P., Queguiner, B., Menesguen, A., Aminot, A., 1997. Impacts of high-nitrate freshwater inputs on macrotidal ecosystems. I. Seasonal evolution of nutrient limitation for the diatom-dominated phytoplankton of the Bay of Brest (France). Marine Ecology-Progress Series 161, 213-224.

Gagnaire, B., Thomas-Guyon, H., Burgeot, T., Renault, T., 2006. Pollutant effects on Pacific oyster, Crassostrea gigas (Thunberg), hemocytes: screening of 23 molecules using flow cytometry. Cell Biology and Toxicology 22 (1), 1-14.

Gagnaire, B., Gay, M., Huvet, A., Daniel, J.-Y., Saulnier, D., Renault, T., 2007. Combination of a pesticide exposure and 
a bacterial challenge: in vivo effects on immune response of Pacific oyster, Crassostrea gigas (Thunberg). Aquatic Toxicology 84 (1), 92-102.

Galois, R., Blanchard, G., Seguignes, M., Huet, V., Joassard, L., 2000. Spatial distribution of sediment particulate organic matter on two estuarine intertidal mudflats: a comparison between Marennes-Oléron Bay (France) and the Humber Estuary (UK). Continental Shelf Research 20 (10-11), 1199-1217.

Goberville, E., Beaugrand, G., Sautour, B., Treguer, P., Team, S., 2010. Climate-driven changes in coastal marine systems of western Europe. Marine Ecology-Progress Series 408, 129-U159.

Goulletquer, P., Heral, M., 1997. The history, present condition and future of the molluscan fisheries of North and Central America and Europe. In: MackenzieJr., C.L., Jr.Burrell., V.G. (Eds.), NOAA Technical Report. NMFS, Europe, pp. 137-164.

Guarini, J.-M., Sari, N., Moritz, C., 2008. Modelling the dynamics of the microalgal biomass in semi-enclosed shallow-water ecosystems. Ecological Modelling 211 (3-4), 267-278.

Havens, K.E., James, R.T., East, T.L., Smith, V.H., 2003. N: P ratios, light limitation, and cyanobacterial dominance in a subtropical lake impacted by non-point source nutrient pollution. Environmental Pollution 122 (3), 379-390.

Hussenot, J., 1998. In: Hussenot, J., Buchet, V. (Eds.), Marais Maritimes et aquaculture. Activité durable pour la préservation et l'exploitation des zones humides littorales. IFREMER, Rochefort, p. 278.

Legendre, L., Rassoulzadegan, F., 1995. Plankton and nutrient dynamics in marine waters. Ophelia 41, 153-172.

Lemonnier, P., 1980. Les Salines de l'Ouest. Logique technique, logique sociale. Éditions de la Maison des Sciences de l'Homme/PUL, Paris, France, pp 222.

Loreau, M., Mouquet, N., Holt, R.D., 2003. Meta-ecosystems: a theoretical framework for a spatial ecosystem ecology. Ecology Letters 6 (8), 673-679.

Lorenzen, C.J., 1967. Determination of chlorophyll and phaeopigments: spectrophotometric equations. Limnology and Oceanography 12, 343-346.

Lotze, H.K., Lenihan, H.S., Bourque, B.J., Bradbury, R.H., Cooke, R.G., Kay, M.C., Kidwell, S.M., Kirby, M.X., Peterson, C.H., Jackson, J.B. C., 2006. Depletion, degradation, and Recovery potential of estuaries and coastal Seas. Science 312 (5781), 1806-1809.

Lougheed, V.L., Crosbie, B., Chow-Fraser, P., 2001. Primary determinants of macrophyte community structure in 62 marshes across the Great Lakes basin: latitude, land use, and water quality effects. Canadian Journal of Fisheries Aquatic Sciences 58 (8), 1603-1612.

Lubchenco, J., Olson, A.M., Brubaker, L.B., Carpenter, S.R., Holland, M.M., Hubbell, S.P., Simon, A.L., MacMahon, J.A., Matson, P.A., Melillo, J.M., Mooney, H.A., Peterson, C.H., Pulliam, H.R., Real, L.A., Regal, P.J., Risser, P.G., 1991. The Sustainable Biosphere Initiative: an ecological research Agenda: a Report from the ecological Society of America. Ecology 72 (2), 371-412.

Lucassen, E., Smolders, A.J.P., van de Crommenacker, J., Roelofs, J. G.M., 2004. Effects of stagnating sulphate-rich groundwater on the mobility of phosphate in freshwater wetlands: a field experiment. Archiv Fur Hydrobiologie 160 (1), 117-131.

Meybeck, M., Helmer, R., 1996. In: Chapman, D. (Ed.), Water quality assessments - A guide to use of biota, sediments and water in environmental monitpring. E\&FN Spon, London, p. 651.

Millennium Ecosystem Assessment, 2005. Ecosystems and Human Well-Being: Wetlands and Water Synthesis. World Resources Institute, Washington, DC, p. 68.

Mitsch, W.J., Cronk, J.K., Wu, X., Nairn, R.W., Hey, D.L., 1995. Phosphorus Retention in constructed freshwater riparian marshes. Ecological Applications 5 (3), 830-845.
Morales-Baquero, R., Carrillo, R., Reche, I., Sanchez-Castillo, P., 1999. Nitrogen-phosphorus relationship in high mountain lakes: effects of the size of catchment basins. Canadian Journal of Fisheries and Aquatic Sciences 56 (10), 1809-1817.

Nõges, P., van de Bund, W., Cardoso, A., Solimini, A., Heiskanen, A.-S., 2009. Assessment of the ecological status of European surface waters: a work in progress. Hydrobiologia 633 (1), 197-211.

Pinckney, J.L., Paerl, H.W., Tester, P., Richardson, T.L., 2001. The role of nutrient loading and eutrophication in estuarine ecology. Environmental Health Perspectives 109, 699-706.

Rojo, C., Baron-Rodriguez, M.M., Alvarez-Cobelas, M., Rodrigo, M. A., 2010. Sustained primary production with changing phytoplankton assemblages in a semiarid wetland. Hydrobiologia 639, 55-62.

Rozas, L.P., Odum, W.E., 1988. The rôle of submerged aquatic vegetation in influencing the abundance of nekton on contiguous tidal fresh-water marshes. Journal of Experimental Marine Biology and Ecology 114 (2-3), 289-300.

Sand-Jensen, K., Borum, J., 1991. Interactions among phytoplankton, periphyton, and macrophytes in temperate freshwaters and estuaries. Aquatic Botany 41 (1-3), 137-175.

Schindler, D.W., 1977. Evolution of phosphorous limitaion in lakes. Science 195 (4275), 260-262.

Seitzinger, S.P., 1988. Denitrification in freshwater and coastal marine ecosystems: ecological and Geochemical significance. Part 2: comparative ecology of freshwater and marine ecosystems. Limnology and Oceanography 33 (4), 702-724.

Shimodaira, H., 2002. An Approximately Unbiased test of Phylogenetic Tree Selection. Systematic Biology 51 (3), 492-508.

Sintes, E., Martinez-Taberner, A., Moya, G., Ramon, G., 2004. Dissecting the microbial food web: structure and function in the absence of autotrophs. Aquatic Microbial Ecology 37 (3), 283-293.

Smith, V.H., Tilman, G.D., Nekola, J.C., 1999. Eutrophication: impacts of excess nutrient inputs on freshwater, marine, and terrestrial ecosystems. Environmental Pollution 100 (1-3), 179-196.

Sokal, R., Rohlf, F., 1995. Biometry San Fransisco.

Souissi, S., Yahia-Kefi, O.D., Yahia, M.N.D., 2000. Spatial characterization of nutrient dynamics in the Bay of Tunis (south-western Mediterranean) using multivariate analyses: consequences for phyto- and zooplankton distribution. Journal of Plankton Research 22 (11), 2039-2059.

Strain, P.M., Yeats, P.A., 1999. The relationships between chemical measures and potential Predictors of the eutrophication status of Inlets. Marine Pollution Bulletin 38 (12), 1163-1170.

Suzuki, R., Shimodaira, H., 2006. Pvclust: an R package for assessing the uncertainty in hierarchical clustering. Bioinformatics 22 (12), 1540-1542.

Talureau, R., 1965. L'aménagement des marais et l'avenir de l'Ouest Atlantique, Paris.

Tong, S.T.Y., Chen, W., 2002. Modeling the relationship between land use and surface water quality. Journal of Environmental Management 66 (4), 377-393.

Tovar, A., Moreno, C., Mánuel-Vez, M.P., García-Vargas, M., 2000. Environmental Implications of intensive marine aquaculture in Earthen ponds. Marine Pollution Bulletin 40 (11), 981-988.

Verhoeven, J.T.A., Arheimer, B., Yin, C., Hefting, M.M., 2006. Regional and global concerns over wetlands and water quality. Trends in Ecology \& Evolution 21 (2), 96-103.

Vitousek, P.M., Aber, J.D., Howarth, R.W., Likens, G.E., Matson, P.A., Schindler, D.W., Schlesinger, W.H., Tilman, G.D., 1997. Human alteration of the global nitrogen cycle: sources and consequences. Ecological Applications 7 (3), 737-750. 
Volkmar, E.C., Dahlgren, R.A., 2006. Biological oxygen demand dynamics in the Lower San Joaquin River, California.

Environmental Science \& Technology 40 (18), 5653-5660.

Weller, M., 1978. In: Good, R.E., Whigham, D.G., Simpson, R.L. (Eds.), Freshwater Wetlands: Ecological Processes and Management Potential. Academic Press, New York, pp. 267-284.

Wiesler, F., Horst, W.J., 1993. Differences among maize cultivars in the utilization of soil nitrate and the related losses of nitrate through leaching. Plant and Soil 151 (2), 193-203. 